\title{
Locating Zhuhai between land and sea: a relational production of Zhuhai, China, as an island city
}

\author{
Gang Hong \\ Sun Yat-sen University, Zhuhai, China \\ honggangsysu@163.com
}

\begin{abstract}
Despite an abundance of representations that focalize Zhuhai's island and coastal features in both academic and popular discourses, serious engagement with the lived sociogeographic realities of the 'city of a hundred islands' are few and far between. As a critical reaction, this paper seeks a relational production of Zhuhai, China as an island city with specific urban island spatiality. The focus/locus problematic is deployed within the wider context of the relational turn in island studies. First, representations that bring Zhuhai's islandness into focus are categorized and analyzed. It is questioned whether these discourses have constructed for the city an organic collective self that identifies with island and marine values. In an effort to de-focus Zhuhai's island and coastal geographies and re-produce them as locus, a series of place-specific relational issues pertinent to urban island studies are addressed, such as the relationship between island spatiality and city formation, land-sea configurations, and the nature of urban public space between land and sea. It is argued that the island city of Zhuhai's imaginaries and the concretization of its island and coastal possibilities follow a trajectory that is island conscious and mainland unconscious. To propose alternative theoretical models for a more nuanced understanding of the lived realities of the island city of Zhuhai and island cities in general, the paper concludes by re-contextualizing the focus/locus dichotomy within the wider theoretical framework of the relational turn in island studies.
\end{abstract}

Keywords: focus and locus, island cities, land-sea configurations, relational turn, urban island studies, Zhuhai

https://doi.org/10.24043/isj.16

(C) 2017 - Institute of Island Studies, University of Prince Edward Island, Canada.

\section{Introduction}

The city of Zhuhai (珠海), with its 146 or so islands and islets and its coastline totalling around $543 \mathrm{~km}$, is officially publicized as the 'City of a Hundred Islands' (百岛之城) (《珠海市志》广东省珠海市地方志编撰委员会, 2001, p. 98). A prefecture-level city on the Pearl River Delta, Zhuhai is composed not only of densely urbanised delta islands that are regarded as part of the mainland but also of numerous offshore islands. These offshore islands include those of the Dan'gan Archipelago (担杆列岛) and Jiapeng Archipelago (佳彭列岛), which are themselves part of the wider Wanshan Archipelago (万山群岛), extending out across the south of the delta region. The Gaolan Archipelago (高栏群岛), meanwhile, is located in Zhuhai's extreme southwest, and further small islands fringe the city's coasts.

Despite the heterogeneity of the islands and islets within the city's borders, existing academic engagement is largely confined to economic and eco-environmental discourses, which more often than not reify the islands into discrete functions, such as objects for tourism profiteering or detached scientific dissection (see 元, 2015; 卢\&司, 2014; 张\&陈, 2007; 黄 \& 王, 2000; 颜 et al., 1992; 温 et al., 1987; 朱, 1987 for examples of economic and eco-environmental discourses about 
Zhuhai's islands in Chinese academic circles). As a result, the existing academic literature tends to make Zhuhai's islands the locus of study yet fails to bring them into focus.

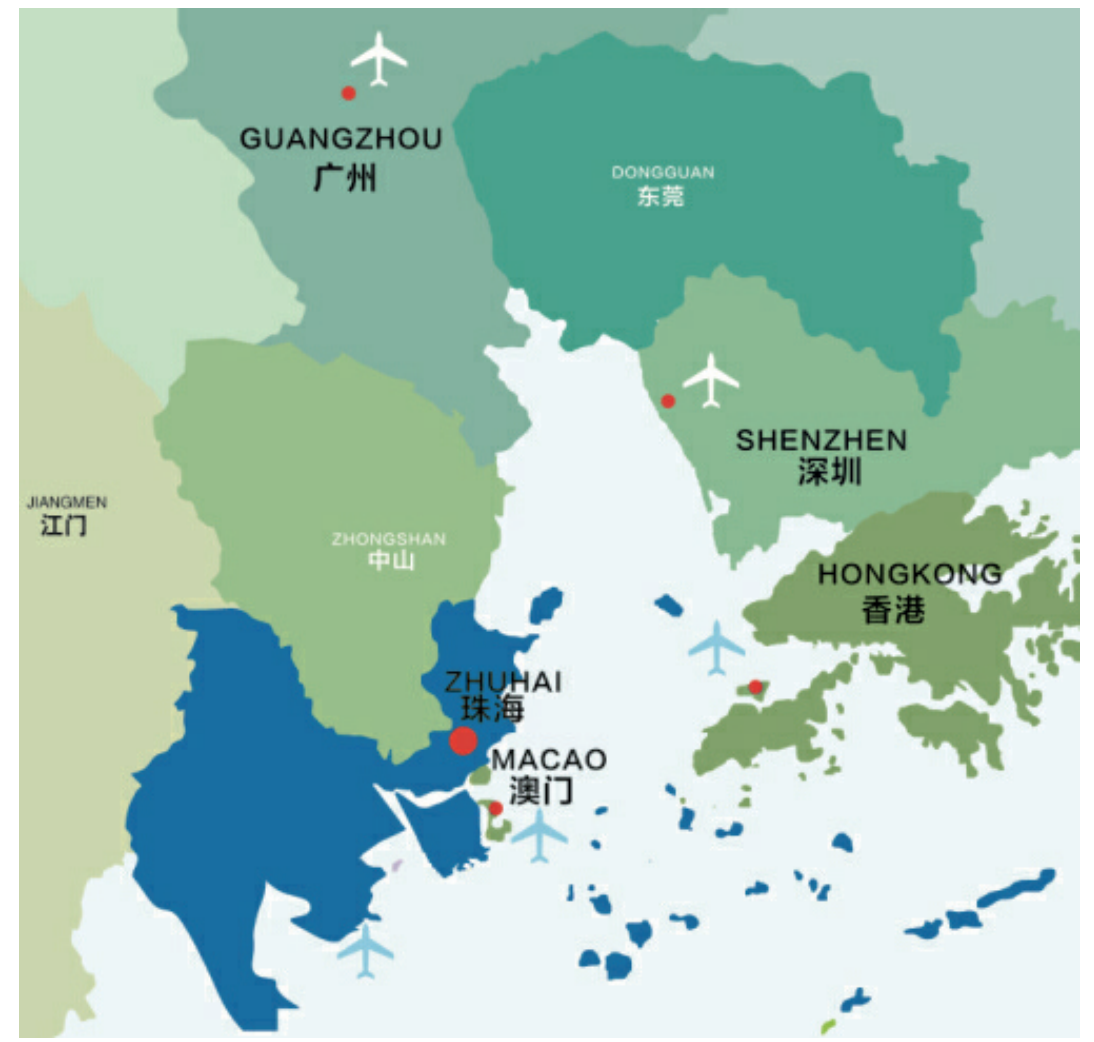

Figure 1: Zhuhai (dark blue) is a prefecture-level city in China's Pearl River Delta. Note the Wanshan Archipelago extending across the south of the delta. (Source: City of Zhuhai (C) 2015, http://www.cityofzhuhai.com/2015-10/29/c 45739.htm)

The present paper aims for an understanding, on both empirical and conceptual levels, of Zhuhai's island geographies as they become manifest at the intersections of different relations in the particular locale of the city. I start by analyzing the efforts of various Chinese discourses to bring Zhuhai's islands into focus. These efforts are visible in four dominant genres of cultural representation of Zhuhai's islands, namely, 1) tourism discourse; 2) official publicity discourse; 3) city chronicle discourse; and 4) ideological discourse. I argue that despite their differences, they share a tendency to approach the city of islands as pure focus in the absence of locus.

In face of this discursive reductionism, I attempt to approach the city of islands as both focus and locus, that is, not just as islands in discourses but also as islands of concrete sociomaterial existence. The paper addresses two major relational concerns of urban island studies as set forth by Grydehøj (2015a, 2015b) in order to produce islands as both focus and locus: 1) the relationship between terrestrial-marine spatiality and Zhuhai's city formation and 2) predominant patterns of land-sea configuration in urban Zhuhai. In addressing the former concern, I emphasize the sociopolitical interpretation of terrestrial-marine relationships as a historically crucial factor in the formation of this very young city, whereas in addressing the latter concern, I emphasize three predominant patterns of land-sea configuration in the city as well as various determining factors in its working processes. The three predominant patterns of land-sea configuration are:

1) islands or islets serving as fetishized symbols of otherworldly leisure or unspoiled nature for the mainland;

2) land extending visually/metaphorically into the sea;

3) solidification of the water realm for trade expansion. 
The determining factors involved in these patterns include:

1) state strategy;

2) local economic profiteering;

3) the gaining of political leverage via urban image-building and place branding.

It is argued that the island city of Zhuhai's imaginaries and the concretization of its island and coastal possibilities follow a trajectory that is island conscious and mainland unconscious. In the last part of the paper, I return to a theoretical re-contextualization of the focus/locus construct by situating it within the more general framework of the relational turn in island studies which has taken place during the past decade or so. More nuanced categories for future studies are proposed with the hope of offering a holistic and dynamic understanding of the problem underlying the focus/locus dichotomy.

\section{Zhuhai's islands as focus}

\section{Theoretical context}

Ronström's (2012) thoughts on the paradoxical relationship between islands as focus and islands as locus provide a fitting theoretical platform for our discussion on the islandness of Zhuhai. Ronström seeks to bring into sharp relief the chasm between islands as focus (in which islands are foregrounded in the spotlight of cultural representations) and islands as locus (in which islands $\mathrm{can}$ /should be reinserted into the soil of lived social realities). Ronström argues that the bringing of islands into focus usually comes at a price; as an island becomes the object of cultural and academic gazes, its ideological uniqueness is disclosed while its actual existences are concealed.

This kind of problematization is by no means unique to Ronström's academic branch, ethnology, but has been a major frame of reference within which most branches of contemporary humanities and social sciences in the west perceive and analyze the world. The differences among these branches lie more in the object of thinking than in the pattern of thinking: for instance, in literary studies, we speak about Shakespeare as use value or as exchange value (e.g., Wilson, 1995, pp. 91-103), whereas in historiographic studies, we speak of history as reality or fiction (e.g., White, 1987, p. 54). Nonetheless, it must be conceded that there is a difference when we apply this manner of thinking in island studies, namely that, given laymen's habitual perception of islands as being more natural objects than cultural constructs, their problematization can shed light on the complexity of islands as both focus and locus.

Ronström's endeavour is a critical reaction to a tendency since the early 1990s within island studies to ignore the island as locus while focusing on representations of the island. In his words, "As representations are the focus of my study, the question becomes: what about the island as locus?" (Ronström, 2012). He discerns effects of the cognitive turn, that is, the impulse to generalize the locus of island to the extent that any intrinsic qualities of particular islands are lost. "To most ethnologists the island is a mere locus, not the focus of study, and as locus it is generalized to the extent that it becomes substitutable to just about any other place" (Ronström, 2012). This critical reaction to the 1990s cognitive paradigm could be understood as broadly in line with the relational turn that has to varying degrees become conventionalized, not only in island studies, but also across various disciplines in humanities and social sciences. My understanding is that while the focus/locus tool works well for analytic purposes, the relational paradigm is most illuminating in reflections of a more theoretical nature. Therefore, I will stick to the focus/locus model in the analytic parts of the paper before engaging with a theoretical reflection within the more general context of the relational turn in island studies near the end of the paper.

Similarly, in the treatment of Zhuhai's islandness by the prevailing cultural and academic discourses of mainland China, the city's islands have been dealt with either as focus or locus (more often as mere focus, it seems) but never as focus and locus. This functional and discrete understanding of islands in Zhuhai is manifested in the following excerpts of representation. 


\section{Predominant island discourses}

The following excerpts from official and civic discourses in China fit well with what Ronström (2012, p. 54) calls a "generic island speech" that exists as a master signifier, indiscriminatingly attachable to any island in the world. They are representations of Zhuhai's islands from online tourist brochures, the city government website, and a city chronicle officially compiled by local authorities. (The author translated the following five excerpts into English from their original Chinese.)

\section{A) Excerpts from online tourist brochures:}

1) He Bao Island, with its natural and ecologically balanced environment and beautiful scenery featuring beaches, reefs, waves, forest and mountain streams $[\ldots]$ constitutes a giant-scale pictorial scroll in which sea and sky merge into a Buddhist-like netherworld [...] A vast span of subtropical virgin forest is to be found on the island with many mountain streams incessantly flowing through the woods. A long-lasting warm and moist summer with no winter makes the island an ideal place for leisure and holidaymaking. (https://lvyou.baidu.com/hebaodao/?from=zhixin)

2) Dong Ao Island [...] is the classic island for seaborne tourism in Zhuhai city, widely known as the 'city of a hundred islands' [...] The primitive natural environment has been preserved with a variety of densely grown plants; there are wild sea views and delicate woodland scenery; there are primitive landscapes and historical relics; there are terrestrial characteristics and the marine world [...] The beauty of the sea can be enjoyed in full through a series of activities, including diving in the deep, playing on the beach, fishing on the banks, and cruising around the island. (https://lvyou.baidu.com/dongaodao/?from=zhixin)

3) Wai Lingding Island [...] is known for its magic beauty and elegant tranquillity, with an ensemble of stones and a waterfront environment. With harsh winter and hectic summer almost unknown to the island's climate, four seasons on the island coalesce into an endless spring. The island is characterized by typical subtropical rain forest scenery, and with all its rich tourist resources could be rightly called an Eden in the sea [...] Aloof from the noise of mundane life in the city, the newly urbanized and renovated Wai Lingding Island makes an ideal place for leisure, holidaymaking, conferences and training sessions of all sorts. (http://lvyou.baidu.com/wailingdingdao/?from=zhixin)

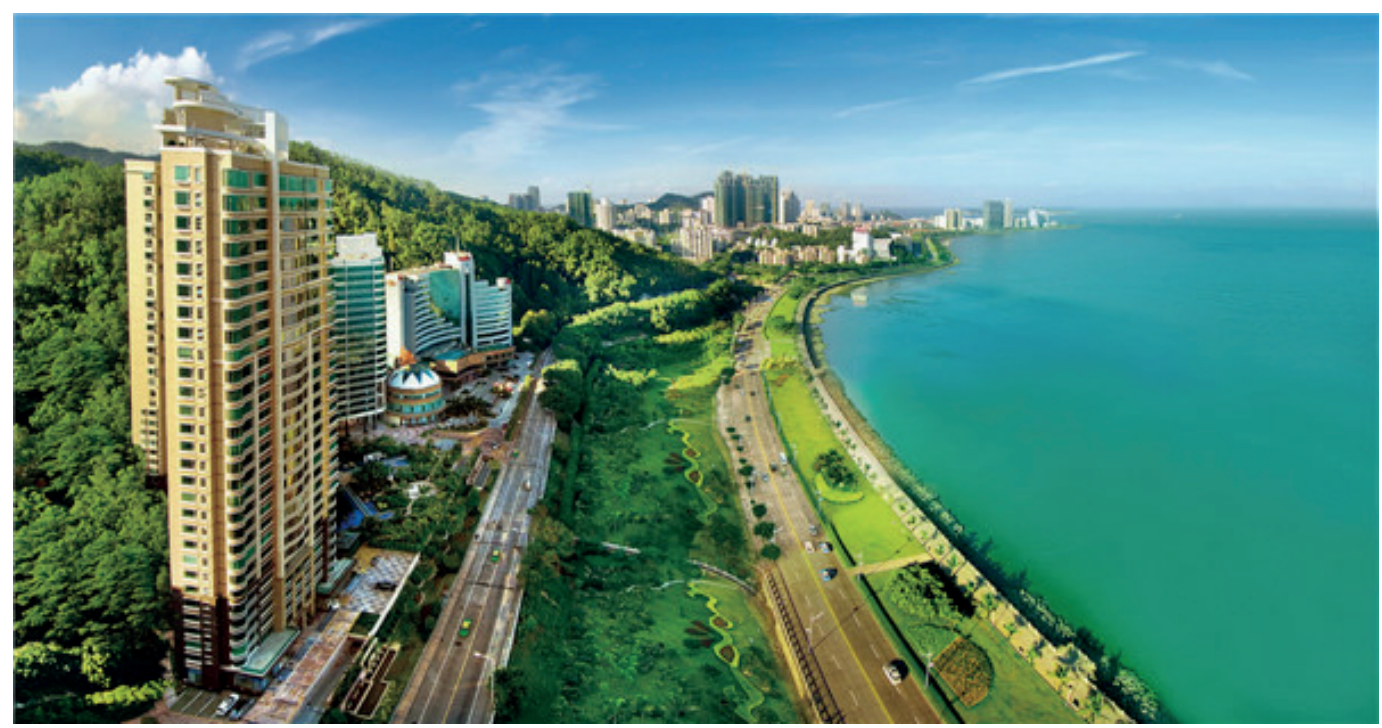

Figure 2: Lovers' Road, a coastal boulevard running alongside downtown Zhuhai. (Source: City of Zhuhai (C) 2015, http://www.cityofzhuhai.com/2016-03/14/c 50078.htm) 


\section{B) Excerpt from the city government website:}

4) 'Romantic Zhuhai' / Woken every morning by sunlight / stroking the subtropical wind with outstretched hands / and the heart-shaped leaves of Bauhinia trees / the heart throbs with happiness [...] Touched every night by tender sentiments / stroking the subtropical wind with outstretched hands / and the heart-shaped leaves of Bauhinia trees / the heart grows restless with tender feelings / Human figures on Lovers' Road keep waiting and waiting / light from faraway fishing boats beckon to the illuminated streetlamps on the shore / go see the Fishing Girl monument [...] only in the light of pearls / loving people take vows to each other, witnessed by sea and mountain / Zhuhai, the city of the young and the romantic / Zhuhai, the city of love. (http://www.zhuhai.gov.cn/yjzh/mlzh/)

\section{C) Excerpt from official city chronicle}

5) The city of Zhuhai, with its marine territory covering 6,135 kilometres, hosts a total of 146 islands and islets, scattered between 2 major archipelagos and 8 chains of islands of smaller scale. The aggregated coastline of all of the islands and islets amounts to $543.03 \mathrm{~km}$ and covers $236.93 \mathrm{~km}^{2}$. The city ranks first among all of the counties and cities in the province in terms of the number of islands in the sea [...] The islands in Zhuhai hold sufficient heat and offer abundant lighting. Some of them also feature mangroves, which are known as 'forests in the sea'. These mangroves are a habitat for more than 50 species of wild plants and 102 species of birds, such as cuckoos, which make up one-fifth of the total number of bird species (511 altogether) in the whole South China region.

(《珠海市志》广东省珠海市地方志编撰委员会, 2001, p. 98)

These five excerpts epitomize the generic representations of Zhuhai's islands to which most people have access. There is, of course, a degree of variation. In the first three excerpts, islands are objectified into natural playthings for leisure and tourist consumption. In the fourth excerpt, islands are fetishized into objects of desire with an erotic touch. Although the fifth excerpt appears more objective, it nonetheless reduces the islands into the mere object of a museum-like gaze. If Zhuhai's islands have been treated as locus, this locus has been so thoroughly generalized as to allow these islands to be substituted with any other island in the rest of the world. In other words, the islands have been approached not as a manifestation of different relations in both temporal and spatial dimensions, but as the pure projection of human subjectivity obsessed with different functionalities.

More complex ideological island discourses

While the simplistic representations of the islands of Zhuhai shown above seem prevalent in popular circles, extended and complex narratives abound in discourses of a more serious nature, such as memoirs, cultural treatises, and historical literature (e.g., 孙 et al., 2012, pp. 106-112; 刘, 2005; 王 et al., 1998; 珠海市文明办, 1998). Diverse as they appear on the surface, these narratives share a tendency to represent the islands of Zhuhai in an explicitly or implicitly ideological manner.

In this type of discourse, the word 'island' is not a foregrounded signifier as in the popular discourses above but has instead retreated into the background and slid into metonymy alongside a range of semantic equivalents such as 'shore', 'ocean', 'trade', 'the west', 'openness', 'modernity', and 'progress'. Islands as locus have evaporated without a trace.

A typical instance can be found in historical narratives featuring local celebrities. Given the hegemony of economic narratives, authentic historical narratives about Zhuhai are few and far between. However, it would be unfair to say that no history is told about the city. There is plenty. But most such historical narratives could be subsumed under the genre of economic discourse. Foregrounded symbols of this sub-genre include historical figures born in the region embraced by today's Zhuhai at around the end of the 19th century, which roughly marks the start of the 
modern era in orthodox Chinese historiography. These individuals are either early overseas expatriates who returned home to invest (such as the patron of Mei Xi Pai Fang (刘, 2005, pp. 47-53) or early overseas students who were sent abroad by Qing officials and returned to build schools and spread western thoughts (such as Rong Hong (刘, 2005, pp. 131-134). These figures inescapably foreground the city's marine status as a hotbed for Chinese modernity, one of whose overriding themes, at least insofar as official ideology is concerned, is the myth of overcoming anxiety by embracing Occidental ways.

\section{Do these discourses produce an organic collective self?}

The problem of identity represents a central concern for cultural studies. Contemporary cultural studies has received much impetus from non-orthodox approaches to identity. In brief, orthodox theory assumes that the self is an autonomous subject (best represented by the Cartesian ego cogito), "stable and independent of all external influences" (Edgar \& Sedgwick, 2002, pp. 183-184). Cultural studies relies on approaches that assume identity to be no more than a response to something external to and different from it, that is, an other. Ever since the late 19th century, theorists from a variety of fields such as sociology (e.g., Emile Durkheim, George Herbert Mead), psychoanalysis (e.g., Sigmund Freud, Erik Erikson, Jacques Lacan), and structuralist Marxism (e.g., Louis Althusser) have competed to offer varieties of this other, all to a varying degree and on different levels embracing the aforementioned relational stance on identity (Edgar \& Sedgwick, 2002, pp. 184-186). Especially relevant to our discussion is Foucault's view on identity in his later writings. Foucault pinpoints the construction of the 'self through its positioning within discourses. In this constructive process, the self is "theorized in terms of the conceptual and other intellectual resources that it calls upon in order to write or talk about itself" and "in the way in which it is written about, or written to" (Edgar \& Sedgwick, 2002, p. 187).

In light of the theoretical concern above, our question becomes: does a city have a self? Or, to express it in a more literary manner: does a city have a soul? Some scholars believe it does. Swaminathan's (2015) interpretation of the identity construction of the island city of Mumbai through the city's abundance of narratives and social imaginaries is a case in point. Swaminathan's overall presupposition is that a city is both a "physical structure" and an "organic body," which is "poetically and metaphysically portrayed as having a soul" (Swaminathan, 2015, p. 35). Starting from this presupposition, he argues that Mumbai's soul has largely been the product of narrative construction and social imaginaries in which geographic features such as sea, coast, and ports are crucial elements.

Swaminathan's interpretation of Mumbai as an island city provides several nodes from which possible connections to Zhuhai's experience as an island city could be built. I will list them below in descending order of relevance to Zhuhai's experience:

a) geographic elements of sea, coastal features, and ports;

b) official identification with urban, modern, and global collective self;

c) huge gap between rich and poor, dire social stratification, and apparent zonal differentiation;

d) the status of being a liberal upstart against a wider backdrop of state-led economy and nationalist ideology; and

e) the role of narrative construction incorporating coastal features and forms in the formation of organic social imaginaries.

Insofar as a), b), and c) are concerned, Zhuhai has much in common with Swaminathan's Mumbai. Zhuhai's geography is known for its maritime, coastal, and portal environments. Besides, publicity about the city undertaken by both municipal and state institutions rely upon an imaginary centering around elements that symbolize urban, modern, and global values, as has been indicated by our above discussion concerning prevailing discourses of the city's history. Moreover, in a sociological sense, Zhuhai's urban and island landscape is fundamentally shaped by an uneven distribution of wealth and social resources, as is the case with many densely urbanized island cities worldwide. However, it is in d) and e) that Zhuhai's experience diverges from that of Swaminathan's Mumbai. Swaminathan 
(2015, p. 36) can compare Mumbai to an intriguing movie in which "fact and fiction merge, angles and dimensions intermingle, and science and folklore intersect," and he repeatedly refers to the soul of Mumbai as a unique island city. He seeks to emphasize the extent to which physical structures (such as coastal features and island geography) are capable of shaping the city and its residents' imaginaries of self and thereby influencing their individual and social life patterns.

In contrast, I doubt whether Zhuhai is also a movie. I doubt whether in Zhuhai fact and fiction merge. I doubt whether Zhuhai has been able to use narratives to construct a collective soul as organic as that of Mumbai, as seen through Swaminathan's eyes. Above all, I doubt whether crude elements such as sea, coasts, and ports have been metaphorized into the tissues of the city and its residents. My doubts stem from the fact that, ever since 1978, Zhuhai has been central - rather than peripheral - to the state's vision of development. Liberal possibilities offered by Zhuhai's coastal features are securely embedded in the general framework of state-led industrialization and commercialization. Despite its relatively flourishing liberal economy compared with more inert mainland cities, Zhuhai's private sectors have never been able to rival state-owned enterprises. One of the products of this developmental pattern is the virtual absence of robust indigenous culture industries. Narratives about the city incorporate many elements characterized by seaborne horizons and coastal features, but these elements are largely deployed to articulate desires of a collective and national nature rather than desires associated with the "private enterprise and free markets" of Swaminathan's (2015, p. 45) Mumbai. In short, if fact and fiction merge in Swaminathan's Mumbai, fiction featuring coastal and island geographies of Zhuhai only serves to overshadow fact — not because there is insufficient fiction but because there is too much fiction of the same genre.

\section{Zhuhai's islands as locus}

\section{Locating Zhuhai as an island/mainland city}

Although the 'island' signifier has indeed been used both literally and metaphorically (e.g., Andexlinger, 2015), the island dimension of Zhuhai is not at all metaphoric. However, the city is not a typical island city in the sense of being a single island cut off from the mainland by water on all four sides. In fact, this kind of typical island is perhaps to some extent utopian; it is, at most, only one object of research among many others. One of the most significant contributions of urban island studies lies in its will to resist the temptation to romanticize the definition of 'island' through the standard of perfect insularity from the mainland. From this perspective, islands that are linked to the mainland by bridge, tunnel, or causeway and islands that have merged with the mainland through land reclamation are recognized as true islands (Grydehøj et al., 2015). With just a slight bit of exaggeration, it could be said that an island city only exists as the intersecting and crisscrossing of a series of spatial relations.

The city of Zhuhai is composed of estuary islands in the Guangdong region. Zhuhai is just one of numerous distinct island cities in China's Pearl River Delta, facing the South China Sea. The large number of islands and islets scattered across the city's marine territory forms one of South China's most extensive ensembles of archipelagos (《珠海市志》广东省珠海市地方志编撰委员会, 2001, p. 98).

With respect to island urbanism, Grydehøj et al. (2015, p. 5) propose two major kinds of island cities: 1) "strongly urbanised small islands and archipelagos" and 2) "major population centres located on largely rural islands or archipelagos." Zhuhai is closer to the first of these categories, though it is an imperfect fit. By the standards of similar island cities such as New York and Singapore as well as regional peers such as Macau, Hong Kong, and even Shenzhen, the extent to which and the mode in which Zhuhai is urbanized are likely to be subject to suspicion. Furthermore, Zhuhai's connection to the vast Chinese hinterlands to the north and to the west confounds the city's outward-looking impulse with an inward-looking reluctance, which makes it a dubious subject of consideration in comparison with more urbanized island cities worldwide. 


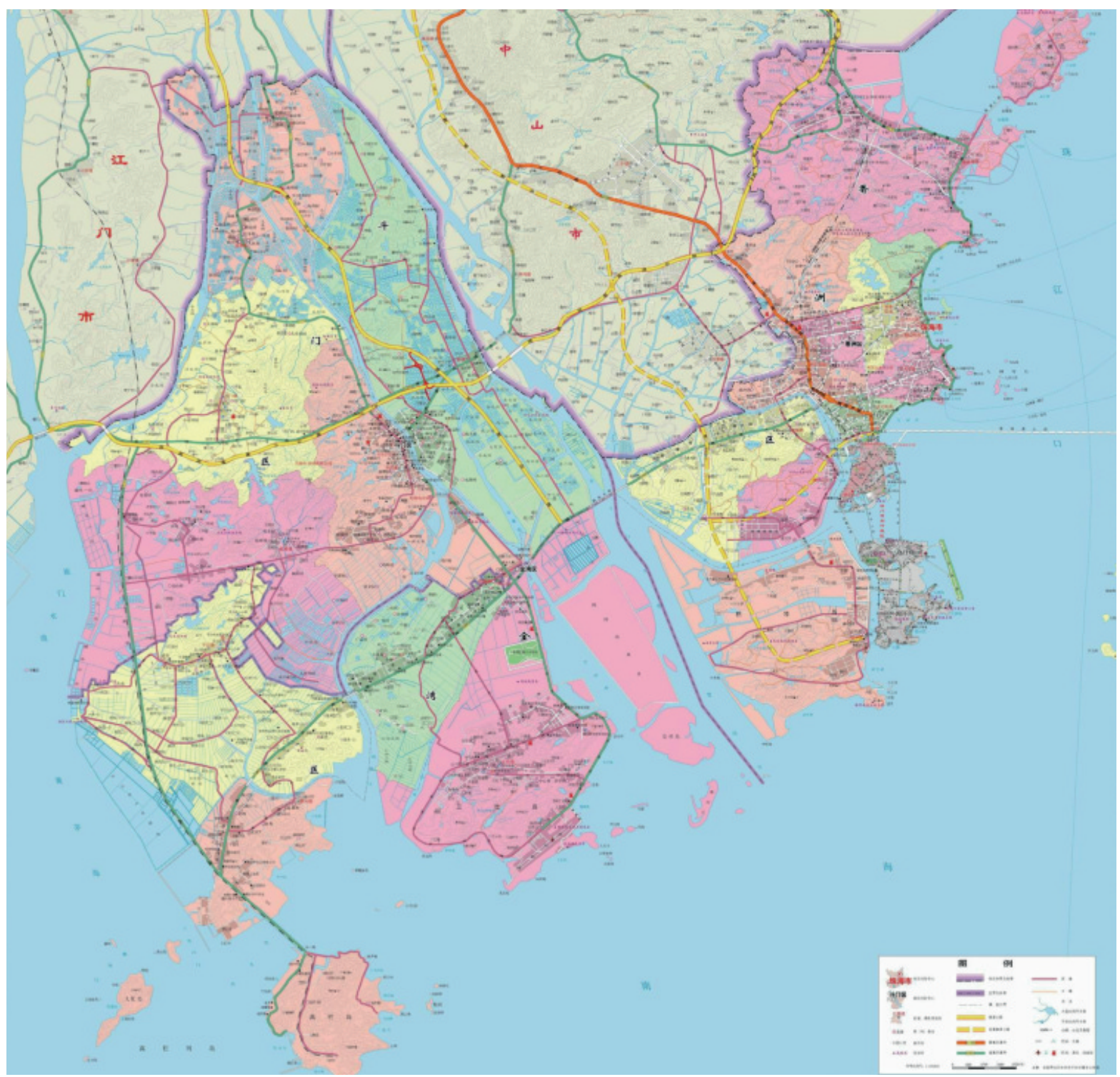

Figure 3: Map of Zhuhai. The city centre is located in Xiangzhou District, on the east of the map, bordering Macau. The Gaolan Archipelago lies to the extreme southwest. (Source: $\underline{\text { http://xzqh.info) }}$

Terrestrial-marine spatiality and the formation of the city of Zhuhai

A prominent relational issue instantiated in urban island studies is the close relationship between islands as locus and city formation. To some scholars, the relationship seems so self-evident that one can spot a coincidence - if not causality — of them at high frequency. As Grydehøj (2015a) repeatedly argues, "Islands and cities coincide," "cities are particularly likely to occur on small islands and archipelagos," "Major cities [...] and islands go hand in hand." The argument rings as true in Grydehøj's global overview of island cities as it does in the local case of Zhuhai. This is even more so because the locus of the island city plays a decisive role in its formation.

In fact, in Zhuhai's case, island as locus is so decisive that it is misleading to use the verb 'form' to describe the birth of the island city. 'Form' connotes a certain sense of slow natural process, yet, instead of just coming into being, Zhuhai was virtually called into existence by the central government in Beijing several years after the end of the Cultural Revolution (see 卢et al., 2001, pp. 112-116, for an official account of this history). Why was the city called into existence so suddenly? What factors played a role in this process? Different answers could be given to questions of this nature, and I wish to engage with the type of explanation provided by urban island studies. 
Asserting the necessity of urban island studies, Grydehøj (2015a) proposes three basic benefits of island spatiality: territorial benefits, defence benefits, and transport benefits. The city of Zhuhai, which is one of the five Special Economic Zones (经济特区) dotted around China's southeastern coastal regions, was officially called into existence in 1980 (卢et al., 2001, p. 33). What are the main drivers behind the creation of the city on the part of Chinese Communist Party elites up north in Beijing?

In light of the three benefits of island spatiality proposed by urban island studies, trading desirability and water-borne transport benefits are of primary importance. The city's island spatiality was expected to be exploited for trade by attracting foreign investment (especially from the neighbouring island cities of Macau and Hong Kong, as well as from Taiwan in the early years). The city was also expected to export everyday agricultural commodities (especially to Hong Kong and Macau in the early years) and less significantly to function as an interface between South China Sea and mainland China supply routes (see 卢et al., 2001, p. 102, for an official account of this history).

The roles of trading desirability and transport benefits in Zhuhai's urbanization process are inversely evident in the agoraphobic period during the anti-rightists' campaign and the Cultural Revolution. From 1956 to the end of the Cultural Revolution in 1976, the mainland interior was granted paramount importance in virtually all aspects of social-economic-political-cultural life. The highly centralized government placed absolute importance on class struggle and microscopically state-planned economy. There are three reasons for this: one is the limited resources expected to be invested in the mainland interior; the second is political fear of counter-revolutionary activities coming from across the sea; the third concerns the then-dominant extreme-left ideology, which regarded coastal areas as the "frontlines of class struggle" (阶级斗争前哨) (王et al., 1998, pp. 219-220). Remnants of these former ideological positions are still evident in today's Zhuhai.

In former times, the coastal area of today's Zhuhai was marginalized in most aspects of social life. On 4 October 1961, the entire Zhuhai area was classified as a 'border defence area' (边防区). On 27 July 1962, the headquarters for an anti-illegal emigration and anti-sabotage campaign (反偷渡、反破坏行动指挥部) was set up (《珠海市志》广东省珠海市地方志编撰委员会, 2001, pp. 17-24). After May 1969, most farmers and businessmen in Zhuhai gave up doing business and transitioned to non-commercial professions as the state stepped up efforts to control cross-border trade between Zhuhai and Macau. Meanwhile, since local foreign trade companies could not guarantee punctual shipping services, the cross-border flower trade between Zhuhai and Macau gradually decreased before ceasing completely. In 1971, the Zhuhai area hosted a movement targeting illegal emigration and civilians attempting to flee overseas, mostly to Hong Kong. However, real historical processes are always dialectic: in the later years of the Cultural Revolution (1973-1976), the foreign trade department of the provincial government in Guangdong conducted trading system reforms, involving the establishment of bases for manufacturing export commodities (mainly food and agricultural products for Hong Kong and Macau) and the encouragement of selective imports within the limits delineated by the state (王et al., 1998, pp. 225-227).

Zhuhai's island spatiality was not exploited for the creation of a local power centre, given the People's Republic of China's highly uniform and monistic top-down power structure. In a similar vein, Grydehøj (2015a) notes the contrast between the fluidity of Medieval European and Sub-Saharan African conceptions of territory with a lack of borders and of concepts of absolute political authority, and the simpler notions of statehood and political power in contemporary South and East Asian territoriality. Although island spatiality in the area encompassed by today's Zhuhai has not been exploited for a local power centre, it has, in a reverse manner, historically served to reinforce distant state power, centred far away in the northern plains of China.

Historical instances of the aforementioned centralizing process were evident in the Ming Dynasty (1368-1644) and in the early Qing Dynasty (1644-1912). In the Ming Dynasty, the central state shut down the ability of coastal regions to reach beyond the sea. The ban on both 
maritime trade and voyages (海禁) except for official purposes was a basic policy from the central government in the north. Although commodification of agriculture and handicrafts increased during this period around the Guangdong coastal region, including today's Zhuhai area, the result was only an expansion of the exchange market between coastal areas and the mainland interior. In other words, seaborne possibilities were weakened while land-rooted stability was strengthened. The maritime ban lasted for 200 of the 290 years of the Ming reign. In 1370, the Ming government set up Shi-Bo-Si (市舶司) at the island city of Guangzhou. Lang Bai Ao (浪白澳), today's Nan Shui town (南水镇) in Zhuhai, was designated as a port for foreign merchant ships. But insofar as the historical records are concerned, it seems that Shi-Bo-Si's power during this period was totally at the mercy of the class of eunuch officials, a phenomenon unique to the Ming Dynasty.

This situation of strong control by a distant central government engendered piracy and other anti-establishment forces in the civilian world (王et al., 1998, pp. 9-22). In 1393, at Huang Liang Du (黄良都), situated in today's Dou Men (斗门) district, a group of civilians led by Wu Jintian (吴进添) were accused of "organizing civilians and connecting with foreign powers for subversive intents" (结党通番为乱) on San Zao island (三灶岛) in the southwest of today's Zhuhai. The official from the regional capital in Guangzhou dispatched troops to suppress the rebellion, and guards were later stationed on the island to fend off any peasants venturing to farm there (《珠海市志》广东省珠海市地方志编撰委员会, 2001, p. 5).

The obsession with territorial stability and fear of opening up to the sea was further reinforced in the early period of the Qing Dynasty (1656-1684). Besides continued efforts to ban maritime activities (as evidenced by a 1656 imperial decree), there was a 1661 order for residential emigration (迁界令), which forced coastal residents from Shan Dong province in the east to Guangdong province in the south (a vast area, amounting to the majority of China's coastal zone) to emigrate away from the coast and into the interior by $25 \mathrm{~km}$. The order came into force in 1662 and was followed by a 1664 order forcing residents to move another $15 \mathrm{~km}$ into the interior. The latter order covered many prosperous towns in Guangdong, which had formerly been outside of what the central state had regarded as the dangerous contact zone with the sea. This included the town of Xiang Shan (香山) and many islands to the south (excluding Macau) and is likely to have affected much of today's Zhuhai. Farming, voyaging, and fishing were strictly forbidden around these regions, and transgressions were severely punished. It was not until 1684 that residents were permitted to return to their former lands and the occupation of fishing. The maritime trade ban continued (王et al., 1998, pp. 101-103).

With regards to military defence, the third benefit of island spatiality highlighted by Grydehøj (2015a), Zhuhai's extensive coastal territory was formerly regarded as a necessary safeguard against possible military and ideological threats from without. Along Zhuhai's coasts, one can still find today numerous watchtowers that were used for keeping a close eye on domestic refugees attempting to flee to Macau and Hong Kong, especially in the period prior to China's opening and reform in the early 1980s (《珠海市志》广东省珠海市地方志编撰委员会, 2001, pp. 17-24). Such relics of China's past isolationism do not, however, impact Zhuhai's current residents.

Far from 'islanding' (Pigou-Dennis \& Grydehøj, 2014; Baldacchino \& Clark, 2013) China's coastal cities, state policy in the Ming and early Qing Dynasties — and even later — thus sought to comprehensively 'mainland' China, to orient society toward the interior. In other words, the relational configuration of the island geographies was interpreted by the state power in such a way that while the relation between island and continent was solidified, that between island and ocean was closed.

\section{Locating Zhuhai between land and sea}

To consider island city space in relational terms, another important issue is the geographic interface between land and water, which is subject to dynamic human interpretation of the dialectic 
between fluidity and solidity in social, economic, and political terms (Grydehøj, 2015b). Various theorists have proposed different approaches and come up with different terminologies for them. For Hayward (2012), this is the 'aquapelagic assemblages'; for Suwa (2007), it is the "intense and enduring relationship between land and water"; for Casper (2013), it is the 'edge'. Despite the nuances in their respective emphases, these scholars share the conviction that the zone where sea meets land provides an effective lens through which we can perceive the phenomenological coproduction of island and city, geographic structure and human agency (see Hay, 2006, for a phenomenological perspective on the island problem).

The land-sea interface perspective is particularly relevant for a relational production of Zhuhai's islands as locus since the city is complexly composed of various geographic constituents in dynamic relations with each other. These include a highly urbanized mainland (which is itself located on tightly packed estuary islands, a result of centuries of natural and anthropogenic land-creation processes) as well as a series of less-urbanized or uninhabited small islands and archipelagos.

In light of the land-sea interface perspective introduced above, we argue that there are three predominant patterns of land-sea configuration in the production of Zhuhai's islands:

1) islands or islets serving as fetishized symbols of otherworldly leisure or unspoiled nature for the mainland;

2) land extending visually/metaphorically into the sea;

3) solidification of the water realm for trade expansion.

Pattern 1 is mainly manifested in two varieties: A) near-shore islands and islets that are cut off from the mainland city centre yet easily accessible through bridges and automobiles and B) remote offshore islands linked to the mainland city centre through ferries. Examples of A in Zhuhai are Ye Li Island (野狸岛) and Qi Ao Island (淇澳岛) while B is best exemplified by Wai Lingding Island (外伶仃岛), Dong Ao Island (东澳岛), and He Bao Island (荷包岛).

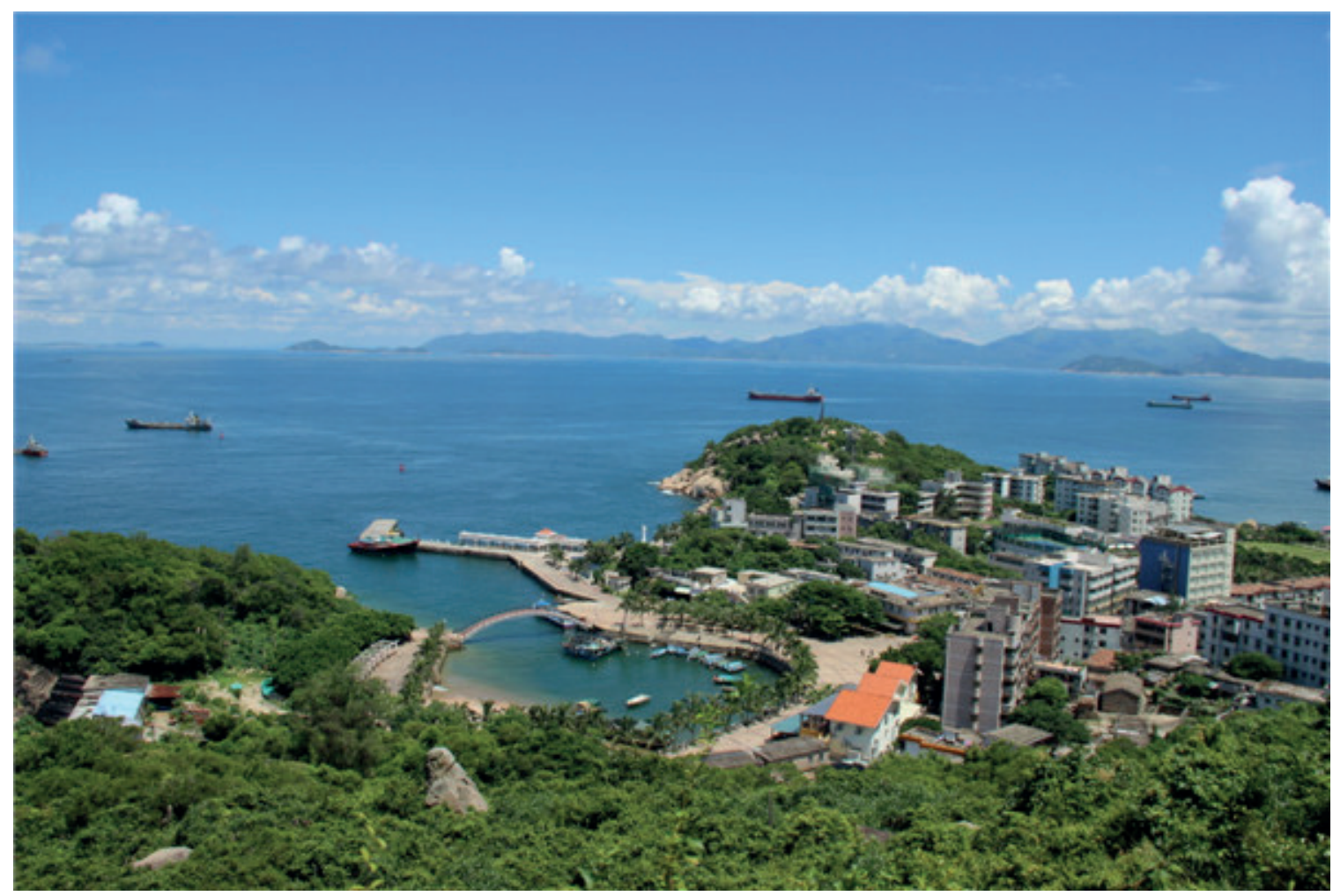

Figure 4: Wai Lingding Island in the Wanshan Archipelago. (Source: (C) City of Zhuhai 2015, http://www.cityofzhuhai.com/2016-03/15/c 50115.htm) 
Pattern 2 (land extending visually/metaphorically into the sea) is mainly manifested in two varieties: A) largely private space consisting of peninsular or coastal habitation clusters and B) dubiously public space consisting of beaches, coastal boulevards, and green lanes. Examples of A are to be found on Hai Yu Peninsula (海愉半岛), Yin Keng (银坑别墅群), and Gree Coast (格力海岸) villa clusters while B is exemplified by various public places and facilities along the coastal boulevard romantically dubbed 'Lovers' Road' (情侣路).

Pattern 3 (solidification of the water realm for trade expansion) is mainly manifested in two varieties: A) remote suburban islands serving exclusively industrial, logistic, or other purposes of a strategic significance and B) cross-border networking realized by either daunting cross-sea bridging projects or land reclamation processes. Examples of A are to be found in Gaolan Port Economic Zone (高栏港经济开发区) and San Zao Island (三灶岛), while B is exemplified by the Hong Kong-Zhuhai-Macau Bridge (港珠澳大桥) and Hengqin Pilot Free Trade Zone (横琴自贸区).

Before entering into further analysis, we may perhaps more precisely designate the three patterns summarized above as 'refigurations' rather than 'configurations' (Valdés, 1987, p. 63) since the prefix 're-' in the former is more effective for explicating human agency's spontaneous role in the two-way process between the framework provided by island geographies and the historical interpretation (undertaken on social, economic, and political terms) of different relations within this framework.

Seen in this light, three social determinants emerge with regard to the historical hermeneutics of land-sea relations in the empirical case of Zhuhai:

1) The factor of state strategy: the will of the central state to profit from more liberal economies (mainly Hong Kong and Macau) within the so-called 'one country, two systems' (一国两制) political framework, legitimated in the early 1980s;

2) The factor of local economic profiteering: the overlapping interest between local and regional developers on the one hand and local government on the other hand, dating back to the real estate frenzy of the early 2000s;

3) The factor of gaining political leverage through urban image-building and place branding: municipal government's desire to gain political leverage by fabricating alternative urban spatialities, starting from the mid-1990s in the context of a relatively poor record of economic performance compared with more robust delta region neighbours such as Shenzhen, Dongguan, and even Zhongshan (see 肖, 2008, pp. 7-8, for an in-depth reflection on this history).

Though these three factors are more or less co-present in the three patterns of land-sea spatiality mentioned above, particular factors predominate in particular patterns:

1) Islands or islets serving as fetishized symbols of otherworldly leisure or unspoiled nature for the mainland: On near-shore islands and islets that are cut off from the mainland city centre yet easily accessible through bridges and automobiles as well as remote offshore islands linked to the mainland city centre through ferries, the dominant factor is the gaining of political leverage through urban image-building and place branding. This is evident, for instance, on Ye Li Island, which is exploited as a leisure haven that is, despite its 'public' status, most accessible to nearby upper-middle class communities. It is also evident on Qi Ao Island, which is preserved as a paradise of unspoiled nature, catering mainly to the getaway daytrip fantasies of well-off, car-owning, middle-class families. Wai Lingding Island, Dong Ao Island, and He Bao Island fit more perfectly in the category of objects of desire for wealthy and upper-middle class families' holiday fantasies in the sense that they provide a weekend haven that is illusorily isolated from the social realities of city life. There are more nuanced scenarios as well: Ye Li Island, despite its middle-class qualities, also shows a tendency toward becoming an object of desire for more elevated social strata insofar as it possesses an extremely fancy restaurant, the outward appearance of which is that of a daunting ancient ship, as well as a pompously designed city opera house (still under construction), the outward appearance of which resembles the famous Sydney Opera House. 
2) Land extending visually/metaphorically into the sea:In spaces of a more private nature, which are nevertheless legally owned by the communist government, consisting of peninsular or coastal habitation clusters, the dominant interest can be none other than the factor of local economic profiteering. The clusters of super-rich villas and upper-middle class properties dotted along the lengthy coastline in northeast and southeast Zhuhai are tokens of the concretization of land-sea interface possibilities, primarily in the interest of property developers, especially major local and regional actors. Examples include the Gree Corporation in the Gree Coast property cluster and the Vanke Corporation in the Hai Yu Peninsula property cluster, and such developments tend to be wholly or partly manufactured through land reclamation. In this game of profiting from land-sea spatiality, there is furthermore an overlapping interest between developers on the one hand and local government on the other, especially since the real estate frenzy, which began in the early 2000s when land trade became the municipal government's primary economic driver.

It would, however, be falling into another ideological trap to surmise that coastal geography in Zhuhai has entirely been at the sway of the profit model in corporate and political elite interest (cf. Grydehøj, 2015b, for such a narrowly critical approach). As a matter of fact, the government is making efforts to manufacture more public space between land and sea. In this process, the desire to gain political leverage through urban image-building and place branding emerges as the dominant factor. Examples of this type are to be found along the lengthy coastal boulevard romantically dubbed 'Lovers' Road' and the various public places and facilities that accompany it, such as Green Lanes (绿道) for cyclists and joggers; Hai Bin Park (海滨公园) and Hai Bin Swimming Pool (海滨泳场), which shelter large numbers of street singers and low-income migrant workers on their days off; and the Xianglu Harbour (香炉湾) beach renovation project, which is theoretically open to all. In this regard, the Zhuhai city government should be given its credit for its efforts to make public the rich and under-explored waterfront landscape.

However, we should guard against undue optimism regarding the authentic sharing of public space since the word 'public' is always a dubious signifier. Which public are we really talking about when we talk about the 'public'? Take the newly renovated Xianglu Harbour beach, for example. The project, which began in early 2015 and was completed in late 2016, aimed to "maintain ecological priority," "restore a historical beach," "forge an urban park," "lift up the city image," and "build together a beautiful Zhuhai," as expressed in the communist-style campaign banners at the renovation site. The publicity emphasizes 'sunshine', 'beach', 'green sea', and 'blue sky'.

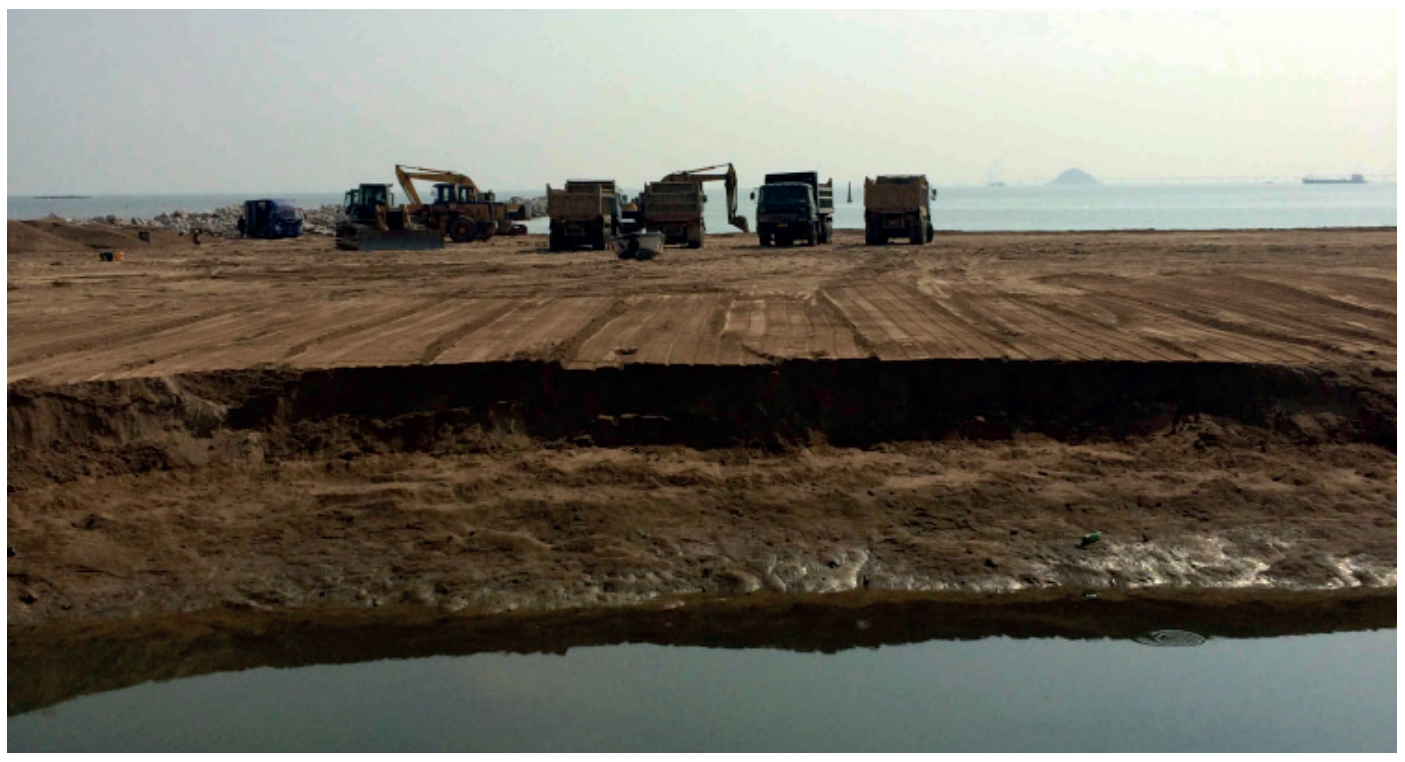

Figure 5: Xianglu Harbour beach, under renovation in December 2015. (Source: C Hong Gang, 2015.) 
This vision seems very beautiful and egalitarian, and in reality everyone does have free access to the beach. My concern, however, is rooted in a chance encounter that I personally experienced, anecdotal though it may be. On a typical day in May 2016, while I was jogging near the beach, I witnessed two uniformed beach guards, probably employed by the local corporation entrusted with managing the space, menacing and pushing a raggedly dressed old man who was seeking to make a small amount of money by collecting used drink cans from a rubbish bin on the beach. The guards were most likely acting upon an unconscious bureaucratic impulse to bully the dispossessed and were probably under pressure from their superiors to maintain a paradise-like beach scene, excluding any presence or act that might mitigate the picturesque purity of the space. Regardless of the guards' specific motives, the beach — despite its superficial public accessibility - is not politically neutral: it is instead managed and interpreted by particular interest groups with particular purposes, not to mention the disproportionately inflated property values near the beach, which offers nearby residents easier and more frequent access.

3) Solidification of the water realm for trade expansion: In both remote suburban islands performing exclusively industrial or trading functions and inter-island bridging or land reclamation projects, what is at stake is primarily state interest. This is manifested in the central state's desire to forge a cross-border network with more liberal neighbouring economies such as Hong Kong and Macau within the political framework of 'one country, two systems'. The Hong Kong-Zhuhai-Macau Bridge is a case in point, as are the efforts to reclaim a cross-border contact zone between Zhuhai and Macau with the purpose of facilitating commercial and cultural exchange (such as Hengqin Pilot Free Trade Zone) and to build a massive integrated system of industry clusters and transportation terminals (such as Gaolan Port Economic Zone). In the three aforementioned projects, the common tendency is an effort on the part of the central state to solidify volatile terrestrial-oceanic inter-geography, boosted by a vision of the great revival of a so-called '21st Century Maritime Silk Road' (21世纪海上丝绸之路). If it is indeed possible for central state and local government interests to dovetail, it remains to be seen whether the public good can, at the end of the day, secure a genuine stake in this game of intra-regional and inter-regional networking, which is both designed and acted out in a top-down power structure.

\section{Between island consciousness and mainland unconsciousness}

We have shown in the previous analysis that island locus has played a significant role in the urbanization of Zhuhai as a very young city. However, though the city in part resembles a "densely urbanized small island" (Grydehøj et al., 2015), the combination of both a mainlanded part and surrounding islands and islets renders the urban landscape more complex, resulting in a series of observations that may be of value to investigations into island cities' urban development.

I will elaborate upon the following two aspects: 1) urban densification and 2) urban zonal differentiation (see Grydehøj, 2015a, for foundational discussion on these points). Since both aspects engage on a general level with the relation between islands and mainland, I will integrate them into a single argument, which could be summarized as follows:

The crucial step in approaching Zhuhai's islands as locus is to become aware of the complex geographic relations of the city, consisting of a major land area merged with the continent to the north and west as well as hundreds of islands and islets dotted along its lengthy coastline to the south and east. For over 30 years, since the early 1980s, this geographic repertoire of relations has been acted out in a manner that is island-conscious and mainland-unconscious. However, during the past few years, there have been palpable signs of restructuration.

My first observation is that on the surface, the conscious focalization of Zhuhai's islands has distinguished the city from many of China's second- and third-tier inland cities in terms of zonal 
diversification (see 肖, 2008, pp. 128-131; 珠海市文明办, 1998 for both popular and official accounts of this history).

My second observation is that, as locus, the city's island urbanism is highly complex: the superficial zonal diversification between island and mainland is questionable in that it is hierarchal rather than equalitarian. For one thing, the mainland part of the city is no doubt the heart of the city insofar as it shelters a conspicuously larger proportion of the population, sells strikingly higher property prices, and offers many more job opportunities and better social services such as retail, healthcare, and education. In this regard, Zhuhai is, after all, not all that different from other mainland cities in China.

Moreover, the majority of islands surrounding the city's mainland have more often than not performed secondary urban functions. In other words, further consideration must be given to the extent to which they are integrated into the city, though most of the islands have already been connected to the mainland by either bridges or ferries. Hayward (2015), taking an environmental perspective, has voiced similar concerns in his reflections on Manhattan, New York. Though not comparable in terms of size, population, or degree of urbanization, Zhuhai and Manhattan could both be deemed what Hayward (2015) regards as the 'unsustainable' variety of 'aquapelagic assemblage', which is characterized by an intensively performative process between terrestrial-marine geography on the one hand and human engagement with it on the other. Hayward's critique of the dominant model of urban planning and development in Manhattan from the mid-1800s to the early 1900s revolves around the conceptual dichotomy between the 'aquapelago' and the 'archipelago'. Whereas the latter refers to "discrete parcels of land dotted within marine environments," the former emphasizes the "integrated terrestrial and marine environments of island aggregates and of human engagement with these" (Hayward, 2015, p. 84). Hayward's preference for the former model is a critical reaction to island studies' longstanding terrestrial model, which treats the marine aspect as something external to the terrestrial one. In response to this, Hayward (2015, p. 93) argues for an "integrated, holistic vision that sees livelihood activities, environmental stewardship and urban planning and development as occurring in dynamic and mutually implicated aquatic-terrestrial assemblages."

A similar charge could be levelled at Zhuhai. For instance, Qi Ao Island, situated in the northeastern part of the city, is appropriated mainly for natural preservation and historical 'heritagization' (Grydehøj, 2014). Ye Li Island, just offshore from the mainland, has been renovated as a leisure space and annexed by one of the downtown districts with the highest property values. These two islands are connected to the mainland by bridges, but more remote offshore islands, such as Dong Ao Island and He Bao Island, can only be reached by boat and therefore serve primarily recreational purposes such as acting as resorts for holiday getaways by city dwellers.

My third observation is that, despite the historical tendency for mainland-centric perspectives on the city (perspectives that incorporate Zhuhai's island geography as pleasant but largely ornamental accompaniments to the mainland centre), the last decade has seen palpable signs of restructuration under the auspices of a new and more complex kind of thinking regarding the city's island/island and island/mainland relations. There have, for instance, been serious attempts to weave a network of small urbanized islands with more outward-looking island cities with colonial pasts in the same region (Macau and Hong Kong). These have been manifested by major government projects such as the Hong Kong-Zhuhai-Macau Bridge, Hengqin Pilot Free Trade Zone, and Gaolan Port Economic Zone. There have also, however, been attempts from the other direction to strengthen the island city's ties with the vast Chinese hinterlands to the north, which have locally been rather weak compared with regional economic powerhouses such as Dongguan and Shenzhen on the eastern side of the Pearl River Delta. Attempts of the second type are embodied mainly in major public transportation projects represented by the Zhuhai section of the Beijing Zhuhai Expressway (京珠高速) and Guangzhou-Zhuhai Intercity Mass Rapid Transit (广珠城轨) (see 孙 et al., 2012, pp. 106-112, for an official-academic account of the aforementioned projects). 


\section{Conclusion: Re-contextualizing the focus/locus dichotomy in the relational turn in island studies}

Following a condensed analysis on Zhuhai's island/mainland geographies as both focus and locus, we now conclude our discussion by returning to a more theoretical reflection upon the focus/locus dichotomy, which has loomed large throughout the analysis. Useful as the dualistic model is for studying Zhuhai's islands, there is a risk of losing sight of the lived realities of the urban island experience if we accept the implicit hierarchization and thereby end up being fixated on either focus determinism or locus determinism. The most pressing issue is to find a conceptual language capable of better representing the lived realities of Zhuhai's island geographies by transcending the rigid dichotomy between focus and locus. As Ronström (2012, p. 9) says:

To allow for this diversity of islands, it is thus necessary to diversify the very idea of diversity by finding a language that makes it possible to study diversity as such, that permits several—diverse — ways of conceptualizing and organizing diversity.

Ronström cites two attempts of this type: one is represented by Pete Hay's (2006) realist approach, which stresses the phenomenologically (pre/non-lingual) productive process between geographic place and human interactions with it, while the other is represented by Lisa Fletcher's (2010) idealist approach, which highlights the constitutive force of discursive (linguistic) acts in the shaping of space. Despite their different emphases, both approaches share a tendency to first cling to and then transcend the focus/locus dualism.

One reason for clinging to the dualism is perhaps the need to participate in an academic community in which certain ways of speaking are accepted as conventions. Certainly, at least with regards to our discussion of the very young Chinese city of Zhuhai, the focus/locus problematique opens up an illuminating field in which one can gain access to the production of Zhuhai as an island city that seems to be vacillating between island consciousness and mainland unconsciousness. However, it is also necessary to revise this approach.

Without completely abandoning the dichotomy, we could re-inscribe it within the more general framework of the relational turn that has taken place during the last decade or so in island studies. There is perhaps not an accurate overall timeline for the emergence and the development of this turn in island studies, yet the field has engaged in a shared effort to disrupt a static interpretation of the focus/locus dualism by foregrounding relationalities, movement, and mobilities, as fleshed out in different contexts of island geographies.

In practice, individual scholars vary in their emphases. Some are moderately structuralist; as with Baldacchino (2006), island studies "need/should not be focused only on islands themselves, but also on relations between islands and mainlands." Others are more constructivist; as with Stratford et al. (2011), island studies should redirect its attention to "island spaces as inter-related, mutually constituted and co-constructed as island and island" because it has been too obsessed with relations between "land and sea," and between "island and continent/mainland." There are still others who take a radical post-structuralist line; as with Pugh (2013), the focus is on the "island-chain archipelago" that is resistant to the tropes of the "static territorial form" and embraces dichotomy-dissolving rhetoric such as "cross-currents," "sea-changes," "force of metamorphosis," "Adamic renewal against tragic overdetermination," etc. Recently, there have also been attempts to "bring together" island studies, critical oceanic studies, and ship studies in thinking relationality not just "within these disciplines," but also "between them" (Pugh, 2016).

What this relational turn in island studies means for our re-examination of the focus/locus dichotomy is that while we acknowledge the effectiveness of its conceptual rigidity in structuring the often too ambiguous realities of island city geographies, we should always guard against the danger of gaining cognitive clarity at the expense of losing existential complexities. Insofar as the experience of the island city of Zhuhai is concerned, these existential complexities could best be 
approached, as Pugh (2016, p. 1054) argues more generally, in terms of a "relational rootedness," which means a "coming to consciousness of different relations in a particular locale," not as a "nomadic flight from the island," but as "the accumulation of island distinctiveness in its own right."

A re-consideration of the focus/locus dichotomy from the perspective of relational rootedness does not mean that we must abandon it altogether. As Stratford et al. (2011) put it, what we need in island studies is "relational paradigms that transcend, and do not merely overturn or reproduce, current classifications and conceptualizations." A more pragmatic solution is to think and speak with Zhuhai's islands in subtler theoretical categories that still stick to the focus/locus parlance while highlighting the relational and processual dimension of it, such as islands as focalization, islands as localization, locus happening in focus, focus concretized at locus, locus resistant to focus, and focus in the absence of locus. Despite the varying degree of viability of these categories in different scenarios, the general aim is to provide a more holistic and dynamic understanding of the focus/locus problematique in a manner that is in line with the relational turn in island studies. Rather than taking the form of a mechanical spatial arrangement, an island city's locus is entrenched in the temporal dimension. An island city's organic potentials can only be realized in a harmonious mesh of the spatial now and temporal past. Furthermore, in so far as island cities are concerned, a dialectic focus/locus enactment demands consideration of a series of interrelations, not just between island and mainland, terrestrial order, and marine prospects, but also-perhaps more importantly-between island geographies and coastal forms in the contrasting imaginaries of multiple social groups.

In the absence of a holistic and dynamic understanding of the spatiotemporal, sociogeographic coproduction of an island city as both focus and locus, we risk what I wish to call island aphasia, symptomized in a series of fixations on mainland, particular islands, particular interpretations of the island/mainland dialectic, particular functions purported for islands, or particular social groups' imaginaries and deployment of islands. Many of these fixations have historically been experienced by the island city of Zhuhai. I hope that this paper has succeeded in raising awareness of guarding against fixations in whatever imaginable forms and opening new horizons for island cities, urban island studies, and even island studies in general.

\section{References}

References in English

Andexlinger, W. (2015). Suburban processes of islandisation in Austria: the cases of Vienna and Tyrol. Urban Island Studies, 1, 118-133. https://doi.org/10.20958/uis.2015.1.7

Baldacchino, G. (2006). Islands, island studies, island studies journal. Island Studies Journal, 1(1), 3-18. Baldacchino, G., \& Clark, E. (2013). Guest editorial introduction: islanding cultural geographies. Cultural Geographies, 20(2), 129-134. https://doi.org/10.1177/1474474012469594

Casper, M. (2013). On land, at sea: formalizing public edges in the archipelago. In N. Bhatia \& M. Casper (Eds.), The petropolits of tomorrow (pp. 106-119). New York: Actar.

Edgar, A. \& Sedgwick, P., (Eds.) (2002). Cultural theory: the key concepts. New York: Routledge.

Fletcher, L. (2010). “... Some distance to go": a critical survey of Island Studies. New Literatures Review, 47-48, 17-34.

Grydehøj,A. (2014). Guest editorial introduction: understanding island cities. Island Studies Journal, 9(2), 183-190.

Grydehøj, A. (2015a). Island city formation and urban island studies. Area, 47(4), 429-435. https://doi.org/10.1111/area.12207

Grydehøj, A. (2015b). Making ground, losing space: land reclamation and urban public space in island cities. Urban Island Studies, 1, 96-117. https://doi.org/10.20958/uis.2015.6

Grydehøj, A., Pinya, X.B., Cooke, G., Doratlı N., Elewa, A., Kelman,I., Pugh, J., Schick, L., \& Swaminathan, R. (2015). Returning from the horizon: introducing urban island studies. Urban Island Studies, 1, 1-19. https://doi.org/10.20958/uis.2015.1 
Hay, P. (2006). A phenomenology of islands. Island Studies Journal, 1(1), 19-42.

Hayward, P. (2015). The aquapelago and the estuarine city: reflections on Manhattan. Urban Island Studies, 1, 81-95. https://doi.org/10.20958/uis.2015.5

Hayward, P. (2012). Aquapelagos and aquapelagic assemblages. Shima, 6(1), 1-11.

Pigou-Dennis, E., \& Grydehøj, A. (2014). Accidental and ideal island cities: islanding processes and urban design in Belize City and the urban archipelagos of Europe. Island Studies Journal, 9(2), 259-276.

Pugh, J. (2016). The relational turn in island geographies: bringing together island, sea and ship relations and the case of the Landship. Social \& Cultural Geography, 17(8), 1040-1059. https://doi.org/10.1080/14649365.2016.1147064

Pugh, J. (2013). Island movements: thinking with the archipelago. Island Studies Journal, 8(1), 9-24.

Ronström, O. (2012). Finding their place: islands as locus and focus. Cultural Geography, 20(2), 153-165. https://doi.org/10.1177/1474474012445446

Stratford, E., Baldacchino, G., McMahon, E., Farbotko, C., \& Harwood, A. (2011). Envisioning the archipelago. Island Studies Journal, 6(2), 113-130.

Suwa, J. (2007). The space of shima. Shima, 1(1), 6-14.

Swaminathan, R. (2015). Port and digital ports: the narrative construction and social imaginaries of the island city of Mumbai.Urban Island Studies, 1(1),35-54.https://doi.org/10.20958/uis.2015.3

Valdés, M.J. (1987). Phenomenological hermeneutics and the study of literature. Toronto ON: University of Toronto Press.

White, H. (1987). The Content of the form. Baltimore MA: John Hopkins University Press.

Wilson, S. (1995). Cultural materialism: Theory and practice. Oxford: Blackwell.

References in Chinese (in phonetic-alphabetic order)

广东省珠海市地方志编纂委员会collective., eds. (2001)《珠海市志》，珠海, 珠海出版社.

黄, 少辉. \& 王, 伟臣. (2000). 珠海万山群岛海上生态公园建设规划设想. 《热带地理》，20(3)，01-21.

刘，权. (2005) 《海外广东人的情结》，广州，广东人民出版社.

刘，小敏. (2005) 《广东人精神之经纬》，广州，广东人民出版社.

卢, 荻. et al. (2001) 《广东改革开放发展史》，北京，中共党史出版社.

卢，锦萍. \& 陈，万灵. (2007). 珠海海岛资源综合开发利用的思路与对策. 《现代乡镇》，20(3)，01-21.

孙，久文. et al., eds. (2012)《中国沿海地区经济转型重大问题研究》，北京，经济管理出版社.

王, 荣武. et al. (1998) 《广东海洋经济》，广州，广东人民出版社.

温, 长恩. el al. (1987). 淇澳岛自然资源及其开发利用. 《热带地理》，7(3)，210-219.

肖，南方. (2008)《珠三角大悬念》，杭州，浙江人民出版社.

颜, 穗航. el al. (1992). 万山的海产贝类资源及其开发. 《生物学教学》，4, 44-45.

元, 炳成. (2015). 珠海淇澳生态岛建设策略研究. 《环境保护与循环经济》，35(9)，14-17.

张，士海. \& 司，庆林. (2014). 国内外海岛开发对珠海的启示. 《新经济》，7，63-67.

朱，国金. (1987). 珠海海岛类型及其资源开发问题的探讨. 《自然资源》，9(4)，37-45.

珠海市文明办collective. (1998). 简论城市形象的内涵. In张汉青. et al (Eds.), 《坚持，发展，探索，创新 : 广东纪念十一届三中全会20周年精神文明建设理论研讨会》(pp. 157-163). 广州: 广州出版社. 